\title{
A call to the Church: Embrace children with disabilities
}

\section{Natalie Ann Flickner ${ }^{a}$}

${ }^{\mathrm{a} B A}$, MA, Writer, Crisis Care Training International

In the world today, two-thirds of the world's children are either children at risk or children in crisis. Among that number are children with disabilities. These children have been abused, abandoned, neglected, and exploited. Crisis Care Training International (CCTI'S), for whom I work, has developed resources and curriculum focused on healing children of trauma, child soldiers, children with HIV/Aids, orphans, street children and children with disabilities across the globe. In 2013, the CCTI founder, Dr. Kilbourn, published a book, "Let All the Children Come," written about children with disabilities. Now, I am writing the CCTI curriculum to help Christian workers, like missionaries, to understand the multi-faceted needs of children with disabilities, not only to understand children with disabilities, but also to learn how to build ministries to share the love of Jesus with them.

Before I share more about why the worldwide church needs to increase its value of and missional action toward children with disabilities, I want to share with you one reason God has called me to write on behalf of children with disabilities - I was one myself.

The night I was born, a newborn had already died in the hospital. My mom had a quick delivery, and I was pronounced a 10 on the Apgar scale. That's a perfect score by the way. But thirty minutes after birth, I was found by a nurse black and blue in my crib. I had stopped breathing, and within critical minutes, my brain was starved of oxygen resulting in mild cerebral palsy. I know, without a shadow of a doubt, that Almighty God was with me in those very moments.

At age two, I still was not speaking. My parents took me to a speech therapist named Carol, and she became a central part of my life. In fact, one of my earliest memories is with Carol, probably around age three. My memory is that I could not pucker to make the "SH" sound, like in "shoe" or "show." So Carol was trying to motivate me to pucker in a fun way by putting lipstick on me. I saw Carol two to three days a week for thirty minutes at a time for the next ten years of my life. However, at age 12, I told my parents "no more!"

I was the first child in my school district to be mainstreamed with multiple physical needs. My parents, along with Carol, had to strongly advocate for my needs in school. The school provided speech, occupational, and physical therapy. But my greatest difficulty in school was handwriting. I had a black typewriter that followed me from 3rd grade until 12th; but not everything in school can be done by typewriter.

Kids were very cruel. I was called retard or cripple. Kids mimicked the way I talked and walked. My mom asked a Girl Scout leader if I could join her troop. It was a troop that most girls from my grade attended. The leader told my mom, "No, because the girls need a break from Natalie." One year, I won first place in the science fair. Kids destroyed parts of my project. Even in youth group at church, a boy mimicked the way I ran in a game.

I frequently cried at school. I always was deeply embarrassed about crying at school, none of the other kids ever did. But as I look back, I realize that I was often physically overwhelmed, bleeding inside from being different and reeling from painful rejection.

But when Jesus came into my life at age 11, my physical struggles did not end. He came to walk with me in my struggles. He changed my heart forever by giving me joy and hope. He has never left me through depression, nor through having a genetic form of arthritis as an adult, nor

Nov 2015. Christian Journal for Global Health, 2(2):61-63. 
through eye problems resulting in glaucoma. $\mathrm{He}$ is my strength and my hope.

There are estimated 95 million to 150 million children in the world who have disabilities. When I say children with disabilities, I am talking about children with spina bifida, Down Syndrome, autism, cerebral palsy, or any other condition at birth. I am also talking about children who have fought as child soldiers, children who were exposed to war, or child laborers who have lost arms, legs, or eyes. Similarly, children who have had accidents in life that left them paralyzed or injured.

Like me, they desperately need the Lord Jesus Christ as their savior from sin and His radical promise of eternal life. God wants these children, the Least of the Least, to hear His Good News and taste the sweetness of a relationship with Him.

Why are these 95 million children the least of the least? Let me tell you. As UNICEF states, "they are one of the most in need, most vulnerable, and most marginalized groups of children in the world."

- They are often declined needed healthcare and basic education.

- They tend to be impoverished throughout their entire lives.

- They endure lives of prejudice, discrimination, and social exclusion.

- They are extremely vulnerable to abuse and exploitation.

I had excellent therapy which allowed me to do my best in life. They don't. Without needed therapy, they can't gain skills like walking, talking, and feeding themselves. In my research, I have read and seen countless stories of children spending their lives in bed or on the floor without the ability to walk, go outside, play, or interact with others. One video tells the story of a boy with polio in a crowded camp in Africa crawling on his hands and knees through muck to visit the latrine before receiving a bucket for personal use. Can you imagine being that boy?
I had a great education. They don't. Millions are never allowed to go to school. Authorities don't want them in school because they think children with disabilities will not go far in education, so why bother? Do you know, that through the UN, over 100 countries signed and passed laws in 2006 for all children with disabilities to be allowed to go to school? But since that law, little to nothing has really changed for children with disabilities. Although seculars see and acknowledge the problem, I believe the only true hope for children with disabilities is through the hope and love of Jesus through the worldwide church. But has the worldwide church acknowledged the dire need of children with disabilities?

I had kids make fun of me. Around the world, whole societies shun children with disabilities. In fact, some parents are so ashamed of having a child with a disability, they never register the child with the government. Many never leave the house. And when they do, not only do children reject them, but also adults. Of course the societal rejection that children with disabilities face is not a direct consequence of disability but rather the society's inability to adapt. God's people should be leading the charge against cultural norms and modeling acceptance of children with disabilities.

I was heartbroken as a child. They are too. I grieved my physical losses. They do too. In fact, children with disabilities have a higher risk than other children for emotional difficulties like depression and anxiety. This fact should cause the church to recognize that childhood disabilities affect the whole child, not just the physical. Therefore, ministries should not only help children physically but also help them thrive socially, emotionally, and educationally. They should be seen as children who have the potential to powerfully affect their homes, communities, and even the world.

I heard the name of Jesus and responded. Do they? Churches overseas often see children with disabilities as demon-possessed or results of $\sin$. 
Because of wrong theology, these children are often forgotten by the church of Jesus Christ.

But, Jesus Himself has not forgotten them. Listen to Isaiah 61:1-4:

The Spirit of the Sovereign LORD is on me, because the LORD has anointed me to proclaim good news to the poor. He has sent me to bind up the brokenhearted, to proclaim freedom for the captives and release from darkness for the prisoners, to proclaim the year of the LORD's favor and the day of vengeance of our God, to comfort all who mourn, and provide for those who grieve in Zion - to bestow on them a crown of beauty instead of ashes, the oil of joy instead of mourning, and a garment of praise instead of a spirit of despair. They will be called oaks of righteousness, a planting of the LORD for the display of his splendor.

Children with disabilities are often poor and the broken hearted. But Jesus came to free them. He yearns to give them strength and hope in this world. With Jesus in their lives, children with disabilities transform from being labeled as weak to becoming strong in faith and unwavering instruments of love. I see endless opportunity for
God to change this world not only for children with disabilities but also through children with disabilities.

Most likely, there are more organizations in the world today that holistically engage children with disabilities than ever before. Some of these organizations are Compassion International, World Vision, and Joni and Friends. Regarding children with disabilities, World Vision's director of Education and Life Skills, Linda Hiebert, said, "Can we ever truly make up for the time we've already lost with the world's most vulnerable children? The answer has to be yes, but it will require everything we've got." I propose that "everything we've got" includes both additional organizations and every individual church throughout the world. Individual churches need to acknowledge the vast needs of children with disabilities, be willing to welcome them, and be a creative bridge between them and the world.

Church, look into the horizon. Imagine all children with disabilities all over the world physically strengthened, included in education, valued in society, emotionally encouraged, and spiritually vibrant! Children with disabilities are worthy as God's children to be equipped to reach their potential and to be celebrated as indispensable contributors to the world-wide church.

\section{Peer Reviewed}

Competing Interests: None declared.

Correspondence: Natalie Ann Flickner, Crisis Care Training International. natalieflickner@gmail.com

Cite this article as: Flickner NA. A call to the church: embrace children with disabilities. Christian Journal for Global Health (Nov 2015), 2(2): 61-63.

(C) Flickner NA This is an open-access article distributed under the terms of the Creative Commons Attribution License, which permits unrestricted use, distribution, and reproduction in any medium, provided the original author and source are properly cited. To view a copy of the license, visit http://creativecommons.org/licenses/by/3.0/

www.cjgh.org

Nov 2015. Christian Journal for Global Health, 2(2):61-63. 